\title{
WOMEN ENTREPRENEURIAL LEADERS AS HARBINGERS OF ECONOMIC GROWTH: EVIDENCES FROM AN EMERGING MARKET OF SOUTH ASIA
}

\author{
Jawaid A. Qureshi \\ Shaheed Zulfikar Ali Bhutto Institute of Science \& Technology (SZABIST), (Pakistan). \\ E-mail: jawaid.qureshi@szabist.edu.pk ORCID: https://orcid.org/0000-0001-6380-5402
}

Salman Bashir Memon

Shaheed Benazir Bhutto University, Shaheed Benazirabad, (Pakistan). E-mail: salman.bashir@sbbusba.edu.pk ORCID: https://orcid.org/0000-0002-4533-4923

Glaire Seaman

Queen Margaret University, Edinburg, Scotland, (United Kingdom). E-mail: CSeaman@qmu.ac.uk ORCID: https://orcid.org/0000-0003-4818-5051

Recepción: 15/06/2021 Aceptación: 02/07/2021 Publicación: 24/08/2021

\section{Citación sugerida:}

Qureshi,J. A., Memon, S. B., y Seaman, C. (2021). Women entrepreneurial leaders as harbingers of economic growth: evidences from an emerging market of South Asia. 3C Empresa. Investigación y pensamiento crítico, 10(3), 137-169. https:// doi.org/10.17993/3cemp.2021.100347.137-169 


\section{ABSTRACT}

Global economy is driven by entrepreneurs operating micro, small, medium, and large-scale enterprises (M-SMLEs). This probe integrates three distinct domains, entrepreneurship, leadership, and gender, particularly women. In a previous study, one of the co-authors investigated such phenomenon that comprised motivations and pre-and-post venture challenges for women entrepreneurial leaders and devised a conceptual framework. This inquiry applies quantitative methods to empirically test and validate such framework, and contribute towards pertinent theoretical underpinning. It avails post-positivism philosophy, deductive approach, and survey method. Data was garnered from women entrepreneurial leaders of Pakistan - a growing emerging market of South Asia. The sample size includes 308 samples (comprising micro, small, and medium-scale enterprises (M-SMEs), 100+ participants from each category. The capabilities, circumstances, and behavior of M-SMEs differ than those of such leaders from large-scale enterprises; therefore, they were ignored purposefully. Structural Equation Modeling (SEM) technique was availed for data analysis. Canons of reliability, validity, and triangulation assisted toward robust results. The findings reveal that motivation to become entrepreneur and need of situation appeared the most significant predictors for starting and leading a venture by women. In challenges before the start of business (discouragement from family and gender stereotypes, financial challenges, lack of entrepreneurial knowledge, and lack of access to market and workplace [in a male-dominated society]) appeared significant predictors in order. And in challenges after the start of business (lack of market research, lack of finance and sustainability, harassment from men, and gender stereotypes from employees) respectively appeared significant predictors of women entrepreneurial leadership.

\section{KEYWORDS}

Entrepreneurship, Female Leadership, Motivation and Challenges, Gender Diversity, Micro, Small, and Medium Enterprises (M-SMEs). 


\section{INTRODUCTION}

Entrepreneurship has become a vast and the most salient discipline having nexus with economics, marketing, strategy, overall management science, sociology, psychology, and so on (Hisrich, Peters, \& Shepherd, 2012). Management scientists have explored entrepreneurs from myriad dimensions by merging it with distinct disciplines, which have substantially contributed to entrepreneurship theory and pertinent frameworks. Entrepreneurship itself has several sub-domains such as, technology innovation, venture capital, microfinance also called micro-entrepreneurship, SME entrepreneurship, green entrepreneurship, and so on (Qazi et al., 2020).

Entrepreneurship is seen from numerous perspectives. It is about bringing creativity into business ventures. Entrepreneurs think in novel ways, develop innovative products and processes, and market the products in unique, efficient, and effective ways. Their ventures can be of any scale, from micro or very small to small, medium, or large-size organizations. Worldwide start-ups observe mushroom growth (Hashi \& Krasniqi, 2011; Qureshi, Qureshi, \& Qureshi, 2018). Entrepreneurs are fueling the global economy by creating employment, income, skill-building, developing new products, processes, and technology, exports, adding value to exchequers' income in the form of taxes (Qureshi, 2012a, 2012b), and playing a vital role in reducing global poverty (Bruton, Ketchen, \& Ireland, 2013).

Leadership has been envisaged from various perspectives, such as a great man or inspirational leader to servant leader. Others see its various characteristics like autocratic, authoritarian, dictatorship, democratic, transaction or task-oriented, and employee or people-oriented (Robbins \& Judge, 2017). Among scholars, consensus has been developed those leaders are influencers (Daft, 2014). Management specialists have ascertained about various sub-domains of leadership by integrating it with several domains of management like strategy and leadership, teams and leadership, entrepreneurial leaders, and women entrepreneurial leaders (Samo, Qureshi, \& Buriro, 2019). 
Researchers noticed new developments in the realm of women entrepreneurship in nexus with leadership (Dean \& Ford, 2017; Dunn, Gerlach, \& Hyle, 2014). Women have been actively participating in almost every field and sector and their participation in business and politics seem growing (Hoyt \& Murphy, 2016). However, women still face prejudice in corporate world to other professions (Lawless \& Fox, 2012). Fair participation of women in all the branches of work life and inclusive equal opportunities for women appears a prime concern for policy makers, governments, and other actors of civil society (Hoyt \& Murphy, 2016). Several authors found difference between masculine and feminine norms and identified problematic leadership styles (Dean \& Ford, 2017; Wilson \& Tagg, 2010). Several researchers agreed that cases of successful entrepreneurial leadership of women need further inquiries in different contexts and environments (Dean \& Ford, 2017; Dunn, Gerlach, \& Hyle, 2014; Harrison, Leitch, \& Mcadam, 2015; Matsa \& Miller, 2014).

Globally, economic growth and sustainable development mainly rest on entrepreneurs. In the success of entrepreneurial ventures, leaders play a pivotal role in leading teams and wielding scare resources. As organizations contain diversified workforce with ever-escalating role of women as business leaders, while their leadership styles and capabilities need to be ascertained. Some authors recommended studying entrepreneurship and leadership together (Leitch \& Volery, 2017). Scholars highlighted research gap to further ascertain entrepreneurial leadership with regard to women leaders (Dean \& Ford, 2017; Kimbu et al., 2021; Kimbu et al., 2021; Santos \& Neumeyer, 2021). In addition, in the context of emerging markets of South Asia, empirical studies need to be conducted by integrating these three distinct domains and to discover the motivations for women to resume and lead a venture, challenges they undergo at preinception stage and post-inception stage, which relate with push and pull theory of entrepreneurship (Samo et al., 2019). Moreover, gender parity in Pakistan stood the third and fourth worst in the world during 2019 and 2021 respectively (Ahmed, 2019; Iqbal, 2021; The World Economic Forum, 2021). Moreover, gender parity and women empowerment pertain to goal number five of the United Nations 
Sustainable Development Goals (United Nations, 2021). Hence, this necessitates undertaking an empirical inquiry.

\section{LITERATURE REVIEW}

The term entrepreneurship is associated with novel ideas for new business with innovative goods, services, and brands that eventually contribute towards sustainable economic development (Goel \& Joshi, 2017). Entrepreneurs have been observed with unique traits and characteristics. Most of them appear creative, proactive, risk-taking, stubborn, having relentlessness and passion, persistent, and humble. Many of them inaugurate a venture after getting some education, job experience, savings, and establishing a network of professionals and supporters. But this differs for many individuals who might resume a venture as a compulsion due to non-availability of jobs, income, etc. It is termed as necessity entrepreneurship theory and refugee entrepreneurship theory, which falls opposite to entrepreneurship by choice. Authors broadly relate such situations with 'push and pull theory of entrepreneurship' (Amit \& Muller, 1995; Dawson \& Henley, 2012; Gilad \& Levine, 1986; Kirkwood, 2009; Patrick, Stephens, \& Weinstein, 2016). Family business and communities in business preferably focus and prioritize their own ventures. Global business is dominated by family business (Qureshi et al., 2018).

Entrepreneurship is a process that can be taught and learnt (Aulet, 2017). Bill Aulet (2017) observed that entrepreneurship is a craft. It is about developing specialized skills to produce goods or perform services, which vary from small works of pottery, painting, electricians, and mechanics to highly specialized skills of information technology (IT) experts. In the wake of dot cam bubble burst or collapse of many technological firms worldwide, he as the leading entrepreneurial guru from MIT formed his firm views that entrepreneurship is a craft. This fact traces its testimonies from centuries.

Leadership has been ascertained from the perspective of leadership traits, skills, styles, processes, and gender differences (De Vries, Bakker-Pieper, \& Oostenveld, 2010; Fischer, Dietz, \& Antonakis, 2017; Matsa \& Miller, 2014; Mumford, Campion, \& Morgeson, 2007; Sczesny et al., 2004). Their strategic 
skills, proactivity, foresight, optimistic grip on pertinent knowledge, decision-making abilities, expertise and experience differentiate them from managers. Among several styles, the most common include: authoritarian, autocratic and dictators, task-oriented, people-oriented, charismatic, democratic, and laissez-fair to headless leaders [who fully empower their teams for attaining defined goals] (Robbins \& Judge, 2017). Leaders are catalysts as they bring reforms inside organizations and make the best use of resources and teams. Great Leaders are transformational leaders who bring marvelous reforms inside organizations and craft positive values and culture (Brown \& Moshavi, 2005). Leadership, teamwork, and conducive work environment play a pivotal role in developing core competencies and sustainable development of organizations. However, autocratic and dictator-like leaders also exist. There have been examples of unsuccessful leaders, destructive leaders and toxic leaders creating toxic culture to poisonous work environment and abuse their powers to play politics by making lobbies and exercising nepotism (Gallus et al., 2013). Such situations cause incivility, de-motivation, disengagement, job stress, underperformance, and employees' turnover to even utter failure of organizations (Robbins \& Judge, 2017).

Regarding the issue of gender, several authors have focused on cross comparison of women with men as leaders in terms of traits, skills, behavior, and performance differences. Women are perceived to be humble, democratic, less autocratic, and participative in task-related environment (Eagly \& Johnson, 1990). Because of their people-oriented behavior, rather than task-oriented, their team members or subordinates feel happier and more satisfied (Crites, Dickson, \& Lorenz, 2015). Other authors found them more optimistic toward tough future goals and effective mentors for their followers (Eagly \& Johannesen-Schmidt, 2001). In developing the leadership capabilities of women, the cultural context and religious values do matter a lot in individual economies, since such obstructs deter them in building their full potential and career cum leadership capabilities (Manzoor, 2015). Researchers have tried to investigate gender differences in every sub-discipline of management science (Kimbu et al., 2021; Santos \& Neumeyer, 2021). 
In developing countries like Pakistan, women's social status does not turn equal to that of men. They are often discriminated and biased (Kaul, 2018). Men's belief in sexism (that men are strong and superior than women) and stereotypes about women make their role felt be little in education, jobs, and businesses (Delavande \& Zafar, 2013; Imam, Shah, \& Raza, 2014). Women are usually discouraged to commence a business by their immediate family members, relatives, pals, and community to society (Samo et al., 2019).

\subsection{MOTIVATION TO BECOME ENTREPRENEUR}

A lot of people have deep motivation to become entrepreneurs, want to lead a team and enterprise, and make the venture successful (Garcia-Rodriguez et al., 2017; Segal, Borgia, \& Schoenfeld, 2005). Indeed, they chase their dreams via their startup journeys. Samo et al. (2019), categorized motivation (for entrepreneurship) into three ways: internal motivation, external motivation trough social aggrandization, and need and situation. Women entrepreneurial leaders possess intrinsic motivation to kick start their venture (Kirkwood, 2009; Orhan \& Scott, 2001). In the context of urban life, many people look at the success stories of entrepreneurs and get deep inspirations. From successful beauticians to designers, chefs, food business owners, restaurant owners, etc. dazzle them, which is termed as social aggrandization (Harms et al., 2014; Kautonen, 2008). Internal motivation and social aggrandization complement each other. Many female entrepreneurs get fascinated from their desires to lead a team and work on their own terms and conditions to pace of work (Carter et al., 2003; Van Gelderen \& Jansen, 2006). Hence, it is hypothesized that:

H1. Motivation to become entrepreneur has a positively significant relation/effect on women entrepreneurial leadership.

\subsubsection{NEED OF THE SITUATION}

Another form of motivation is need of the situation, which may be positive or negative motivation, like compulsion. Many women were compelled to resume a business venture due to abrupt death of their 
fathers or husbands or guardians. Thus, they were left with no choice to carry on their business or start a venture to make their livelihood. Sometimes they did so to chip in some money in home to meet everescalating outlays (Barrett \& Moores, 2009; Koneru, 2018; Orhan \& Scott, 2001). Another compelling reason was absence of male family members to run a family enterprise (Martinez-Jimenez, 2009). These situations led to the terminologies of necessity entrepreneurship (Hessels, Van Gelderen, \& Thurik, 2008) and refugee entrepreneurship, suitable for refugees (Thurik, Carree, van Stel, \& Audretsch, 2008). Thus, they had to sacrifice their own education, career, and other dreams (Barrett \& Moores, 2009). Hence, it is hypothesized that:

H1.1. Need of the situation (to become entrepreneur) has a positively significant relation/effect on women entrepreneurial leadership.

\subsection{CHALLENGES BEFORE THE START OF BUSINESS}

Enormous amount of research studies has been done on entrepreneurship, but relatively less work is undertaken on pre and post challenges of entrepreneurial journey (Miller \& Le Breton-Miller, 2017; Samo et al., 2019). The issues before their journey comprise: discouragement from family and gender stereotypes, financial challenges, access to market and workplace in a male dominated society, and lack of entrepreneurial knowledge (skills and experiences).

\subsubsection{DISCOURAGEMENT FROM FAMILY AND GENDER STEREOTYPES}

The oriental context differs exponentially than that of western one. In various fields of life, women are not given equal opportunities, such as in job market, business, and social circumstances. They are considered as weak and incompetent. Such gender stereotypes chase them throughout their lives (Dy, Marlow, \& Martin, 2017; Gupta, Turban, \& Pareek, 2013; Orser, Riding, \& Manley, 2006). If they get fascinated to become entrepreneurs or dare to do so due to some compulsion or pressing monetary need, they face resistance from their parents, siblings, and family. In cases where they receive some consent and appreciation, some senior family members stay unpleased for several reasons including their misjudgment 
that they will under-perform and men will exploit them (Azmat \& Fujimoto, 2016; Dhaliwal, Scott, \& Hussain, 2010; Pant, 2015). Hence, it is hypothesized that (Note: H2 and H3 respectively appear implied that challenges before and after start of the business have significant relation/effect on women entrepreneurial leadership):

H2.1. Discouragement from family and gender stereotypes have negatively significant relation/ effect on women entrepreneurial leadership.

\subsubsection{FINANCIAL CHALLENGES}

Another front burner issue in the way of female entrepreneurs is about financial challenges (Giardino et al., 2015; Marlow \& Patton, 2005; Salamzadeh \& Kawamorita-Kesim, 2015). Women belonging to lower and middle classes (so-called bottom of the pyramid [BOP] strata of the society) face stiff problem of access to finance (Brush et al., 2018; Realini \& Mehta, 2015). Their limited savings put barricades in their way. They cannot borrow much from their friends and family, since masses in such socio-economic classes stay hand-to-month or barely able to meet the meager requirements of survival. Dearth of savings and investment, coupled with lack of information about access to finance and markets including dearth of awareness about venture capitalists, micro-finance, small and medium enterprise (SME) finance, or any governmental schemes to uphold their ventures further aggravate their situation (Brush et al., 2018). Hence, it is hypothesized that:

H2.2. Financial challenges have negatively significant relation/effect on women entrepreneurial leadership.

\subsubsection{LACK OF ACCESS TO MARKET AND WORKPLACE (IN A MALE-DOMINATED SOCIETY)}

In countries like Pakistan, society is male-dominated, as men mostly take leading positions in all spheres of life and women get affected in such societies (Godwin, Stevens, \& Brenner, 2006; Kabeer, 2000; Kantor, 2003; Kasturi, 1997). More than half of the population contains females, who are engaged in 
almost all realms of work life, except the jobs of postmen or courier men, taxi drivers, butchers, and hawkers (Muhammad, Warren, \& Binte-Saleem, 2017; Roomi \& Parrott, 2008). Those women who dare to commence their entrepreneurial ventures and take leadership positions confront arduous situations, as they have to interact with male workers, laborers, vendors, dealers, and customers. Inside work place to visiting markets, everywhere they deal with men who mostly remain unwilling to treat them equally. Gender stereotype and parity to gap fall very serious constraints in women's entrepreneurial journey (Brush et al., 2018). Hence, it is hypothesized that:

H2.3. Lack of access to market and workplace (in a male-dominated society) has negatively significant relation/effect on women entrepreneurial leadership.

\subsubsection{LACK OF ENTREPRENEURIAL KNOWLEDGE}

Lack of entrepreneurial knowledge (including skills and experiences) also turns a very severe menace for women entrepreneurial leaders. There is an inedible link between entrepreneurial education (or knowledge, skills, and experiences) and intentions to start a venture (Bae et al., 2014; Barba-Sanchez \& Atienza-Sahuquillo, 2018; Kourilsky \& Walstad, 1998; Ratten, 2016; Zhang, Duysters, \& Cloodt, 2014). In developing countries including Pakistan, women in large remain deficient in acquiring technical knowhow and expertise to experiences for resuming and running their ventures to fulfill their needs and dreams (Pervez, 2013). In their exploratory inquiry, Samo et al. (2019) found that many courageous women leaders admitted that they had no basic and foundation knowledge of entrepreneurship, thus they learnt from trial-and-error method. They wasted a lot of energy, effort, time, and money in obtaining the skill-set required to nourish their business and successfully lead it to sustainable development. Hence, it is hypothesized that:

H2.4. Lack of entrepreneurial knowledge has negatively significant relation/effect on women entrepreneurial leadership. 


\subsection{CHALLENGES AFTER THE START OF BUSINESS}

The challenges after the start of business substantially vary than those at the inception stage. Some of those paramount challenges comprise: lack of market research, lack of finance and sustainability, harassment from men, and gender stereotypes from employees.

\subsubsection{LACK OF MARKET RESEARCH}

Lack of market research puts a heavy barricade in the way of startups (Leonidou, 2004; Raymond, 2018; Trott, 2001; Tushabomwe-Kazooba, 2006). Consumers' perceptions, preferences, buying patterns, decision making, and behaviors assist in developing and offering unique value to customers (Nasution et al., 2011). Market insights also assist in making sales, developing customers, and generating profits for survival and growth. Market orientation to specific industry and segment info seem absent in many cases. Institutional voids exist particularly in under-developed and developing countries, where institutions are neither efficient nor supportive in providing all the mandatory information to entrepreneurs (Gao et al., 2017; Mair, Marti, \& Ventresca, 2012). Hence, being market-oriented by comprehending customers, vendors, dealers, environment, and rivals remains a hefty challenge (Kerin \& Peterson, 2012). Hence, it is hypothesized that:

H3.1. Lack of market research has negatively significant relation/effect on women entrepreneurial leadership.

\subsubsection{LACK OF FINANCE AND SUSTAINABILITY}

The financial challenges or instability confronted by women entrepreneurs in the starting phase of the venture deals with access to finance and raising funds, but in the continuing phase of their venture, they deal with a serious issue of managing cash flows or working capital management. Sales transactions take place on cash and credit, while they need to pour money to meet salaries and other outlays, to procurement of goods. If they incur loss, they need money to overcome their cash deficit. If their business 
flourishes, they need finance for sustainable development (Hisrich Peters, \& Shepherd, 2012; Mayoux, 1999; Orser et al., 2006; Ramadani et al., 2015; Ribes-Giner et al., 2018).

Book-keeping knowledge to managing expansion from revenue and surplus cash remain unwieldy. Many women realize that they lack management skills (Fatoki, 2014). They believed that government offers meager magnitude of assistance towards overcoming their financial needs for business (Malmstrom, Johansson, \& Wincent, 2017). However, providing access to finance and ease of borrowing for women yield in economic development and develop positive perception of banks and financial institutions (Abdullah \& Quayes, 2016). Microfinance banks and institutions (including some non-governmental organizations, NGOs) usually finance very low amount at a very high interest rate. SME banks to conventional banks' schemes to lend SMEs demand proven track record of revenues, profitability, ample resources, equity, and readily sellable or cashable collateral. The question arises that if a firm reaches to that level of success (in a developing country), why should it need borrowing? The policy makers and governments need to seriously address these issues for salvation of startups, female entrepreneurial leaders and SMEs for their contribution in uplifting socio-economic development (Qureshi, 2012b). Hence, it is hypothesized that:

H3.2. Lack of finance and sustainability has negatively significant relation/effect on women entrepreneurial leadership.

\subsubsection{HARASSMENT FROM MEN}

At the inception of their start-up, women face discouragement from family and gender stereotype in a male dominated society, and they face harassment from men even during their venture. Pakistan is among those countries where women often face harassment at workplace (Ali \& Kramar, 2015; Muazzam, Qayyum, \& Cheng, 2016; Zia, Batool, \& Yasin, 2016). Many such cases remain unreported (Hadi, 2018). Despite intervention by government and human rights agencies, laws, rules, and policies have been framed to safeguard people, particularly women from harassment, but their execution appears dubious. 
Women face nagging harassment from men including their sub-ordinates (for women entrepreneurs), co-workers and bosses (for working women), dealers, vendors, customers, and other people in society. They face obscene gestures, double meaning words, messages and calls on their phones and social media accounts, and unwanted closeness to touch at workplace to even public places (Wilder, 2018). Hence, it is hypothesized that:

H3.3. Harassment from men has negatively significant relation/effect on women entrepreneurial leadership.

\subsubsection{GENDER STEREOTYPES FROM EMPLOYEES}

Prior to initiating their venture, women face gender stereotype and discouragement from family, friends, and community to society, and unfortunately, during their venture, they feel such stereotypes from their own employees. The belief in sexism that 'men are stronger and superior' prevails in the society. The male subordinates have doubts in the leadership abilities, skills, expertise, and competence of female leaders. They worry about their (women entrepreneurial leaders) decisions and believe that they are not fit for leadership roles, and can ruin the performance (Dean \& Ford, 2017; Muhammad, Warren, \& Binte-Saleem, 2017; Roomi \& Parrott, 2008). Sometimes, men even do not follow their commands, which results in frustration for women leaders (Samo et al., 2019). Hence, it is hypothesized that:

H3.4. Gender stereotypes from employees have negatively significant relation/effect on women entrepreneurial leadership.

\subsection{THEORETICAL FRAMEWORK}

On the basis of pertinent literature review, insights from underpinning theories and paradigms, a theoretical framework is presented hereunder for empirical testing of their relationships and effect on each other. It contains three predicting variables: motivation to become entrepreneur, challenges before the start of business (including discouragement from family and gender stereotypes, financial challenges, 
lack of access to market and workplace [in a male-dominated society], and lack of entrepreneurial knowledge), and challenges after the start of business (including lack of market research, lack of finance and sustainability, harassment from men, and gender stereotypes from employees), and outcome variable, women entrepreneurial leadership.

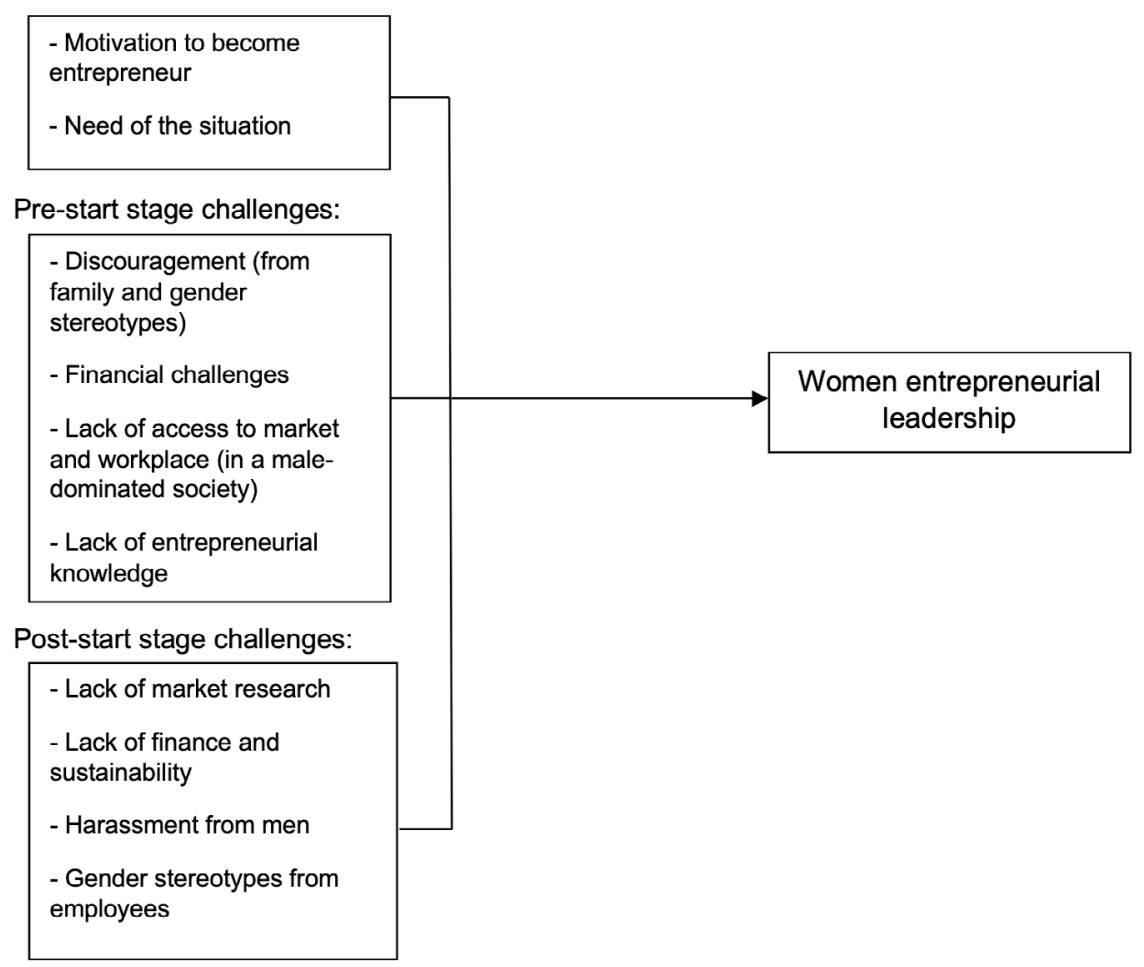

Figure 1. Theoretical Framework.

Source: adapted from Samo, Qureshi, and Buriro (2019).

\section{METHODOLOGY}

We employed an explanatory and quantitative inquiry to empirically test the theoretical framework that we devised by extracting pertinent themes and categories. Utilizing post-positivism philosophy, deductive 
approach and survey method, out of 350 questionnaires distributed, we got 308 questionnaires filled from women entrepreneurial leaders in Karachi, the largest metropolitan hub in Pakistan. The participants belonged to micro, small, and medium enterprises (having 101, 103, and 104 sample sizes respectively). Generally, the capabilities, circumstances, and behavior of M-SMEs largely differ than those of large enterprises. Therefore, we confined ourselves to M-SMEs only. The convenient sampling method was applied. The selection criteria emphasized that they must possess at least five years of experience of leading their ventures successfully for which the success metrics was that they must have creative processes and/or products, risk-takers, and profits within a few recent years. Data was garnered by employing the themes of a qualitative inquiry by Samo et al. (2019). Face or content validity of the instrument, pilot testing, and exploratory to confirmatory factor analyses, and other statistical procedures were performed to ensure reliability, validity, generalizability, and robust results. Structural Equation Modeling (SEM) via Amos was availed for data analysis and empirically testing hypotheses. Eventually, triangulation technique ensured that the findings of the probe resemble with those of analogous inquires (Bashir, Syed, \& Qureshi, 2017; Creswell, 2011; Hair et al., 2011).

\section{DATA ANALYSIS}

We analyzed the significance (of positive and negative) relationship and effect of motivation to become entrepreneur (including need of the situation), and challenges before and after the start of business with women entrepreneurial leadership. Since, we adapted the scale from our previous qualitative probe, so first we applied Exploratory Factor Analysis (EFA) technique to reduce the number of significant components or factors. Then, Confirmatory Factor Analysis (CFA) technique tested the measurement model and confirmed or validated thirty items of ten significant factors.

Using Amos software, structured equation modelling (SEM) was availed to test the hypotheses. Through data normality test, it was learnt that Skewness and Kurtosis stood in the prescribed ranges of \pm 1.5 , which confirmed normality of constructs (Byrne, 2013; Hair et al., 2015). In factor loadings, few items 
with loading up to .5 and insignificant $T$ values below 1.96 values were excluded, and items with loading of .7 and significant $\mathrm{T}$ values up to or greater than 1.96 were taken for further testing. The Eigen values of the core factors excelled the threshold value of 1 (Hair et al., 2015; Henseler, Ringle, \& Sarstedt, 2015). The fitness indices of measurement model stood: $(\mathrm{x} 2=892.123, \mathrm{df}=306, \mathrm{x} 2 / \mathrm{df}=2.915$; CFI $=0.903$; IFI $=.922 ;$ RMSEA = 0.032), which met with benchmark criteria (Koubaa et al., 2014; Schweizer, 2015).

The Table 1 displays that the values of alpha, composite reliability $(\mathrm{CR})$, and average variance extracted (AVE) exceed the benchmark values of .7 (for alpha and CR) and .5 respectively. The values of convergent validity fall greater than the benchmark value of .40, which means that all the measures of constructs correlate theoretically. The correlation values of individual constructs fall below the benchmark value of .90 , which means that the constructs appear non-convergent or distinct from each other and discriminant validity exists (Hair et al., 2010).

Table 1. Reliability and Validity.

\begin{tabular}{|c|c|c|c|c|c|c|c|c|c|c|}
\hline Indicators & MBE & NS & DFGS & FC & LEK & LAMW & LMR & LFS & HM & GSE \\
\hline MBE1 & .831 & & & & & & & & & \\
\hline MBE2 & .822 & & & & & & & & & \\
\hline MBE3 & .812 & & & & & & & & & \\
\hline NS1 & & .815 & & & & & & & & \\
\hline NS2 & & .820 & & & & & & & & \\
\hline NS3 & & .805 & & & & & & & & \\
\hline DFGS1 & & & .791 & & & & & & & \\
\hline DFGS2 & & & .802 & & & & & & & \\
\hline DFGS4 & & & .780 & & & & & & & \\
\hline FC1 & & & & .808 & & & & & & \\
\hline FC2 & & & & .781 & & & & & & \\
\hline FC3 & & & & .765 & & & & & & \\
\hline LEK1 & & & & & .792 & & & & & \\
\hline LEK3 & & & & & .730 & & & & & \\
\hline LEK4 & & & & & .771 & & & & & \\
\hline LAMW1 & & & & & & .765 & & & & \\
\hline
\end{tabular}




\begin{tabular}{|c|c|c|c|c|c|c|c|c|c|c|}
\hline LAMW2 & & & & & & .781 & & & & \\
\hline LAMW3 & & & & & & .721 & & & & \\
\hline LMR1 & & & & & & & .804 & & & \\
\hline LMR2 & & & & & & & .811 & & & \\
\hline LMR3 & & & & & & & .735 & & & \\
\hline LFS1 & & & & & & & & .796 & & \\
\hline LFS2 & & & & & & & & .781 & & \\
\hline LFS3 & & & & & & & & .776 & & \\
\hline HM1 & & & & & & & & & .787 & \\
\hline HM2 & & & & & & & & & .779 & \\
\hline HM3 & & & & & & & & & .745 & \\
\hline GSE1 & & & & & & & & & & .761 \\
\hline GSE2 & & & & & & & & & & .772 \\
\hline GSE4 & & & & & & & & & & .754 \\
\hline Alpha (a) & .861 & .842 & .846 & .841 & .821 & .780 & .771 & .751 & .750 & .743 \\
\hline AVE & .730 & .721 & .715 & .661 & .654 & .621 & .645 & .631 & .639 & .612 \\
\hline CR & .842 & .816 & .840 & .831 & .810 & .794 & .782 & .761 & .741 & .725 \\
\hline
\end{tabular}

Note for abbreviations: Motivation to become entrepreneur (MBE), need of the situation (NS), discouragement from family and gender stereotypes (DFGS), financial challenges (FC), lack of entrepreneurial knowledge (LEK), lack of access to market and workplace [in a male-dominated society] (LAMW), lack of market research (LMR), lack of finance and sustainability (LFS), harassment from men (HM), and gender stereotypes from employees (GSE).

Source: own elaboration.

The results confirmed goodness of fit for overall structured model $(\mathrm{x} 2=836.455, \mathrm{df}=307, \mathrm{x} 2 / \mathrm{df}=$ 2.724; $\mathrm{CFI}=0.922 ; \mathrm{IFI}=.948 ; \mathrm{RMSEA}=0.033)$. The established criteria prescribe that $\mathrm{CFI}$ and IFI should fall within the range of .90 to .95 , while RMSEA should appear close to zero (Schweizer, 2015). The results confirm that motivation to become entrepreneur and need of the situation subsequently have positively significant effects on women entrepreneurial leadership $(\beta=0.322, p<0.00 ; \beta=0.271$, $\mathrm{p}<0.00$ ). The results support $\mathrm{H} 1$ and H1.1. In challenges before the start of business (discouragement from family and gender stereotypes, financial challenges, lack of entrepreneurial knowledge, and lack of access to market and workplace in a male dominated society) respectively have negatively significant 
effects on women entrepreneurial leadership $(\beta=0.231$, $p<0.01 ; \beta=0.222$, $p<0.01 ; \beta=0.210$, $p$ $<0.01 ; \beta=0.185, \mathrm{p}<0.01)$. The results support $\mathrm{H} 2$ with $\mathrm{H} 2.1, \mathrm{H} 2.2, \mathrm{H} 2.3$, and H2.4. In challenges after the start of business (lack of market research, lack of finance and sustainability, harassment from men, and gender stereotypes from employees) respectively have negatively significant effects on women entrepreneurial leadership $(\beta=0.237, \mathrm{p}<0.01 ; \beta=0.214, \mathrm{p}<0.01 ; \beta=0.170, \mathrm{p}<0.01 ; \beta=0.164$, $\mathrm{p}<0.01)$. The results support H3 with H3.1, H3.2, H2.3, and H4.4. As the samples were drawn from four distinct populations, so One Way ANOVA test was applied. The results confirmed that there is no significant difference among the means of the concerned populations.

All the hypotheses were supported and found statistically significant. Among them motivation to become entrepreneur and then, need of the situation appeared the highest positive predictors. In challenges before the start of business (discouragement from family and gender stereotypes, financial challenges, lack of entrepreneurial knowledge, and lack of access to market and workplace [in a male-dominated society]) appeared significant predictors in order. And in challenges after the start of business (lack of market research, lack of finance and sustainability, harassment from men, and gender stereotypes from employees) respectively appeared significant predictors on women entrepreneurial leadership. The preand-post business challenges can negatively affect women entrepreneurial leaders' capability to run a startup successfully.

\section{DISCUSSION AND CONCLUSIONS}

This paper addresses some research gaps and integrates three distinct domains of knowledge comprising women, entrepreneurship, and leadership, and contributes knowledge from a developing country in the oriental region. It contributes in entrepreneurship theories from women entrepreneurial leadership perspective and push and pull theory of entrepreneurship. Pakistan was declared as the fourth worst country in the globe for gender parity (World Economic Forum, 2021). Thus, it necessitates conducting some comprehensive probes to gain insights for theoretical underpinning toward women entrepreneurial 
leadership. We first conducted an exploratory inquiry and designed a framework for explanatory and empirical testing, which is undertaken in this study. This inquiry focuses on discovering the motivations for women to launch their startup, challenges they undergo at embarking phase, and during running the venture as leaders. A sample of 308 women entrepreneurial leaders belonging to micro, small, and medium enterprises (M-SMEs) was drawn with one hundred plus samples from each category.

The results uncover that the chief reasons or motivation behind embarking ventures by women include: internal motivation (containing fascination with urban life, and charms of successful business and leadership for profits, wealth, name and fame, improved quality of life for them and their families, working at their own pace and without any threats from bosses, and contribution to society and economy, social aggrandization or dream to attain social status), and need of the situation (containing no other choice and family compulsion to either resume a venture or lead a family business). Our hypotheses were supported that motivation and need of the situation to become entrepreneur have positively significant relation/effect on women entrepreneurial leadership. The same has been confirmed by (Barrett \& Moores, 2009; Garcia-Rodriguez et al., 2017; Harms et al., 2014; Kaul, 2018; Koneru, 2018).

The challenges that women often undergo before starting the business include: discouragement from family members and gender stereotypes, and financial challenges (due to dearth of investment), and lack of access to market and entrepreneurial knowledge. Our hypotheses were supported that discouragement from family and gender stereotypes, financial challenges, lack of access to market and workplace in a male dominated society, and lack of entrepreneurial knowledge have negatively significant relation/ effect on women entrepreneurial leadership. These results are externally validated too as they resemble with several studies (Balachandra et al., 2017; Barba-Sanchez \& Atienza-Sahuquillo, 2018; Brush et al., 2018; Kimbu et al., 2021; Dy, Marlow, \& Martin, 2017; Muhammad, Warren, \& Binte-Saleem, 2017; Santos \& Neumeyer, 2021).

The challenges that women often undergo after starting phase of the business include: lack of market research, lack of financial sustainability (due to revenues and cash flows problem, initial losses, dearth 
of rationale schemes by banks and lending institutions, and government support regarding financing schemes), harassment, and gender stereotype from employees. Our hypotheses were supported that lack of market research, lack of financial sustainability, harassment from men, and gender stereotype from employees have negatively significant effect on women entrepreneurial leadership. These results seem in coherence with the findings of some analogous inquiries (Dean \& Ford, 2017; Hadi, 2018; Kimbu et al., 2021; Malmstrom et al., 2017; Raymond, 2018; Ribes-Giner et al., 2018; Santos \& Neumeyer, 2021). This probe confirms that women serve as harbingers of economic growth, but in the emerging markets, they do not receive conducive environment for embarking and thriving their ventures.

\subsection{RESEARCH IMPLICATIONS, RECOMMENDATIONS, CAVEATS, AND FUTURE DIRECTIONS}

The managerial implications of this probe suggest that male managers should not under-estimate the capabilities of women entrepreneurial leaders. They should be respected and treated fairly. The rules and policies regarding harassment at workplace need to be exercised strictly inside organizations.

The policy makers at the government level should emphasize and acknowledge the most salient role of women entrepreneurial leaders during the celebrations of "Women Day". This could extoll and appreciate their contribution towards sustainable socio-economic development. In addition, they should insist bankers and lending institutions to re-think micro and SME financing for women by minimizing interest rates, collateral, and other stringent requirements.

The communities and society as a whole can realize the potential and power of women as entrepreneurs and leaders, especially when they see massive public and private campaigns in recognition of role of women during 'International Women Day' celebrations. Hence, the perceptions of society about weak, timid, and incapable women can be reversed gradually.

This paper remained confined to M-SMEs in Karachi city of Pakistan only. In future, several studies can be designed to discover women entrepreneur leaders in the corporate and large-scale enterprises, and 
those from upper echelon of society can be studied. Rural-urban differences in women entrepreneurial leaders, their teamwork, and leadership styles can be investigated from their subordinates. Sector-specific studies can be undertaken. Other developing and under-developed countries can be selected to inquire similar phenomenon for getting indigenous insights.

\section{REFERENCES}

Abdullah, S., \& Quayes, S. (2016). Do women borrowers augment financial performance of MFIs? Applied Economics, 48(57), 5593-5604. https://doi.org/10.1080/00036846.2016.1181831

Ahmed, A. (2019). Pakistan ranks 151 out of 153 on global gender parity index: World Economic Forum report. https://www.dawn.com/news/1522778

Ali, F., \& Kramar, R. (2015). An exploratory study of sexual harassment in Pakistani organizations. Asia Pacific Fournal of Management, 32(1), 229-249. https://doi.org/10.1007/s10490-014-9380-1

Amit, R., \& Muller, E. (1995). "Push" and "Pull" entrepreneurship. Fournal of Small Business \& Entrepreneurship, 12(4), 64-80. https://doi.org/10.1080/08276331.1995.10600505

Aulet, B. (2017). Entrepreneurship is a craft and here is why that's important. Sloan Management Review. sloanreview.mit.edu/article/entrepreneurship-is-a-craft

Azmat, F., \& Fujimoto, Y. (2016). Family embeddedness and entrepreneurship experience: a study of Indian migrant women entrepreneurs in Australia. Entrepreneurship and Regional Development, 28(910), 630-656. https://doi.org/10.1080/08985626.2016.1208279

Bae, T. J., Qian, S., Miao, G., \& Fiet, J. O. (2014). The Relationship Between Entrepreneurship Education and Entrepreneurial Intentions: A Meta-Analytic Review. Entrepreneurship: Theory and Practice, 38(2), 217-254. https://doi.org/10.1111/etap.12095 
Balachandra, L., Briggs, T., Eddleston, K., \& Brush, G. (2017). Don't pitch like a girl! How gender stereotypes influence investor decisions. Entrepreneurship Theory and Practice, 43(1), 116-137. https:// doi.org/10.1177/1042258717728028

Barba-Sánchez, V., \& Atienza-Sahuquillo, G. (2018). Entrepreneurial intention among engineering students: The role of entrepreneurship education. European Research on Management and Business Economics, 24(1), 53-61. https://doi.org/10.1016/j.iedeen.2017.04.001

Barrett, M., \& Moores, K. (2009). Spotlights and shadows: Preliminary findings about the experiences of women in family business leadership roles. Fournal of Management and Organization, 15(3), 363377. https://doi.org/10.5172/jmo.2009.15.3.363

Bashir, S., Syed, S. \& Qureshi, J. A. (2017). Philosophical and Methodological Aspects of MixedMethods Research: A Review of the Academic Literature. Fournal of Independent Studies and Research, $15(1), 32-50$.

Brown, F. W., \& Moshavi, D. (2005). Transformational leadership and emotional intelligence: A potential pathway for an increased understanding of interpersonal influence. fournal of Organizational Behavior: The International Fournal of Industrial, Occupational and Organizational Psychology and Behavior, 26(7), 867-871.

Brush, G., Greene, P., Balachandra, L., \& Davis, A. (2018). The gender gap in venture capitalprogress, problems, and perspectives. Venture Capital, 20(2), 115-136. https://doi.org/10.1080/13 691066.2017 .1349266

Bruton, G. D., Ketchen, D. J., \& Ireland, R. D. (2013). Entrepreneurship as a solution to poverty. Fournal of Business Venturing, 28(6), 683-689. https://doi.org/10.1016/j.jbusvent.2013.05.002

Byrne, B. M. (2013). Structural equation modeling with AMOS: Basic concepts, applications, and programming. Routledge. 
Garter, N. G., Gartner, W. B., Shaver, K. G., \& Gatewood, E. J. (2003). The career reasons of nascent entrepreneurs. Fournal of Business Venturing, 18(1), 13-39. https://doi.org/10.1016/S08839026(02)00078-2

Greswell, J. W. (2011). Controversies in mixed methods research. The Sage handbook of qualitative research, 4, 269-284.

Grites, S., Dickson, K., \& Lorenz, A. (2015). Nurturing gender stereotypes in the face of experience: A study of leader gender, leadership style, and satisfaction. Fournal of Organizational Culture, Communications and Conflict, 19(1), 1.

Daft, R. (2014). The leadership experience. Cengage, United States.

Dawson, C., \& Henley, A. (2012). "Push" versus "pull” entrepreneurship: An ambiguous distinction? International Fournal of Entrepreneurial Behaviour and Research, 18(6), 697-719. https://doi. $\mathrm{org} / 10.1108 / 13552551211268139$

De Vita, L., Mari, M., \& Poggesi, S. (2014). Women entrepreneurs in and from developing countries: Evidences from the literature. European Management fournal, 32(3), 451-460. https://doi. org/10.1016/j.emj.2013.07.009

De Vries, R. E., Bakker-Pieper, A., \& Oostenveld, W. (2010). Leadership= communication? The relations of leaders' communication styles with leadership styles, knowledge sharing and leadership outcomes. Fournal of business and psychology, 25(3), 367-380.

Dean, H., \& Ford, J. (2017). Discourses of entrepreneurial leadership: Exposing myths and exploring new approaches. International Small Business Journal: Researching Entrepreneurship, 35(2), 178-196. https://doi.org/10.1177/0266242616668389 
Delavande, A., \& Zafar, B. (2013). Gender Discrimination and Social Identity: Experimental Evidence from Urban Pakistan. SSRN, 593. https://doi.org/10.2139/ssrn.2198386

Dhaliwal, S., Scott, J. M., \& Hussain, J. (2010). Help or Hindrance? South Asian Women In The Family Firm. Electronic Journal of Family Business Studies (EJFBS), 4(1).

Dunn, D., Gerlach, J., \& Hyle, A. (2014). Gender and leadership: Reflections of women in higher education administration. International Journal of Leadership and Change, 2(1), 9-18.

Dy, A. M., Marlow, S., \& Martin, L. (2017). A Web of opportunity or the same old story? Women digital entrepreneurs and intersectionality theory. Human Relations, 70(3), 286-311. https://doi. org/10.1177/0018726716650730

Eagly, A. H., \& Johannesen-Schmidt, M. G. (2001). The Leadership Styles of Women and Men. Fournal of Social Issues, 57(4), 781-797. https://doi.org/10.1111/0022-4537.00241

Eagly, A. H., \& Johnson, B. T. (1990). Gender and Leadership Style: A Meta-Analysis. Psychological Bulletin, 108(2), 233-256. https://doi.org/10.1037/0033-2909.108.2.233

Fatoki, O. (2014). The Causes of the Failure of New Small and Medium Enterprises in South Africa. Mediterranean Fournal of Social Sciences, 5(20), 922. https://doi.org/10.5901/mjss.2014.v5n20p922

Fischer, T., Dietz, J., \& Antonakis, J. (2017). Leadership process models: A review and synthesis. Journal of Management, 43(6), 1726-1753.

Gallus, J. A., Walsh, B. M., van Driel, M., Gouge, M. G., \& Antolic, E. (2013). Intolerable cruelty: A multilevel examination of the impact of toxic leadership on US military units and service members. Military Psychology, 25(6), 588-601.

Gao, G., Zuzul, T., Jones, G., \& Khanna, T. (2017). Overcoming institutional voids: A reputationbased view of long-run survival. Strategic Management fournal, 38(11), 2147-2167. 
García-Rodríguez, F.J., Gil-Soto, E., Ruiz-Rosa, I., \& Gutiérrez-Taño, D. (2017). Entrepreneurial process in peripheral regions: the role of motivation and culture. European Planning Studies, 25(11), 2037-2056. https://doi.org/10.1080/09654313.2016.1262827

Giardino, G., Bajwa, S. S., Wang, X., \& Abrahamsson, P. (2015). Key Challenges in Early-Stage Software Startups. In International Conference on Agile Software Development, Springer Cham, 52-63. https:// doi.org/10.1007/978-3-319-18612-2

Gilad, B., \& Levine, P. (1986). A behavioral model of entrepreneurial supply. Fournal of Small Business Management, 24, 45.

Godwin, L. N., Stevens, C. E., \& Brenner, N. L. (2006). Forced to play by the rules? Theorizing how mixed-sexfounding teams benefitwomen entrepreneursinmale-dominated contexts. Entrepreneurship: Theory and Practice, 30(5), 623-642. https://doi.org/10.1111/j.1540-6520.2006.00139.x

Goel, M., \& Joshi, B. (2017). Entrepreneurship and Sustainable Development. Fournal of Entrepreneurship and Management, 6(3), 43-51.

Gupta, V.K., Turban, D. B., \& Pareek, A. (2013). Differences Between Men and Women in Opportunity Evaluation as a Function of Gender Stereotypes and Stereotype Activation. Entrepreneurship: Theory and Practice, 37(4), 711-788. https://doi.org/10.1111/j.1540-6520.2012.00512.x

Hadi, A. (2018). Workplace Sexual Harassment and its Underreporting in Pakistan. European fournal of Interdisciplinary Studies, 4(1), 148-153.

Hair, J. F., Black, W. G., Babin, B. J., \& Anderson, R. E. (2010). Multivariate data analysis (7th ed.). Pearson Prentice Hall. New Jersey.

Hair, J. F. J., Celsi, M.W., Money, A. H., Samouel, P., \& Page, M.J. (2011). Essentials of Business Research Methods. Routledge. 
Harms, R., Luck, F., Kraus, S., \& Walsh, S. (2014). On the motivational drivers of gray entrepreneurship: An exploratory study. Technological Forecasting and Social Change, 89, 358-365. https://doi.org/10.1016/j.techfore.2014.08.001

Harrison, R., Leitch, G., \& Mcadam, M. (2015). Breaking Glass: Toward a Gendered Analysis of Entrepreneurial Leadership. Fournal of Small Business Management, 53(3), 693-713. https://doi. org/10.1111/jsbm. 12180

Hashi, I., \& Krasniqi, B. A. (2011). Entrepreneurship and SME growth: evidence from advanced and laggard transition economies. International Journal of Entrepreneurial Behavior \& Research, 17(5), 456-487.

Henseler,J., Ringle, C. M., \& Sarstedt, M. (2015). A new criterion for assessing discriminant validity in variance-based structural equation modeling. Fournal of the Academy of Marketing Science, 43(1), 115-135.

Hessels, J., Van Gelderen, M., \& Thurik, R. (2008). Entrepreneurial aspirations, motivations, and their drivers. Small Business Economics, 31(3), 323-339. https://doi.org/10.1007/s11187-0089134-x

Hisrich, R. D., Peters, M. \& Shepherd, D. (2012). Entrepreneurship (9th ed.). McGraw-Hill Education.

Hoyt, G. L., \& Murphy, S. E. (2016). Managing to clear the air: Stereotype threat, women, and leadership. Leadership Quarterly, 27(3), 387-399. https://doi.org/10.1016/j.leaqua.2015.11.002

Imam, A., Shah, F. T., \& Raza, A. (2014). Mediating Role of Job Stress Between Workplace Discrimination (Gender Discrimination-Glass Ceiling) and Employee Attitudinal Outcomes (Job Satisfaction and Motivation) in Banking Sector of Pakistan. Middle - East Journal of Scientific Research, 19, 401-411. https://doi.org/10.5829/idosi.mejsr.2014.19.3.13615 
Iqbal, N. (2021, April 12). The gender gap. The News.

Kabeer, N. (2000). The power to choose: Bangladeshi Women and Labour Market Decisions in London and Dhaka. Verso.

Kantor, P. (2003). Women's empowerment through home-based work: Evidence from India. Development and Change, 34(3), 425-445. https://doi.org/10.1111/1467-7660.00313

Kasturi, L. (1997). Speaking Out: Women's Economic Empowerment in South Asia. Asian fournal of Women's Studies, 3(4), 131.

Kaul, T. (2018). Intra-household allocation of educational expenses: Gender discrimination and investing in the future. World Development, 104, 336-343. https://doi.org/10.1016/j.worlddev.2017.12.017

Kautonen, T. (2008). Understanding the older entrepreneur: Comparing third age and prime age entrepreneurs in Finland. International Journal of Business Science and Applied Management, 3(3), 3-13.

\section{Kimbu, A. N., de Jong, A., Adam, I., Ribeiro, M. A., Afenyo-Agbe, E., Adeola, O., \& Figueroa-}

Domecq, C. (2021). Recontextualising gender in entrepreneurial leadership. Annals of Tourism Research, 88, 103176.

Kirkwood,J. (2009). Motivational factors in a push-pull theory of entrepreneurship. Gender in Management, 24(5), 346-364. https://doi.org/10.1108/17542410910968805

Kerin, R., \& Peterson, R. (2012). Strategic Marketing Problems (13th ed.). Pearson.

Koubaa, Y., Srarfi, R., \& Ghaabouni, R. (2014). On the use of structural equation modeling in marketing image research. Asia Pacific Journal of Marketing and Logistics, 26(2), 315-338.

Koneru, K. (2018). Women Entrepreneurship in India - Problems and Prospects. SSRN, 3110340. https://doi.org/10.2139/ssrn.3110340 
Kourilsky, M. L., \& Walstad, W. B. (1998). Entrepreneurship and female youth: Knowledge, attitudes, gender differences, and educational practices. Fournal of Business Venturing, 13(1), 77-88. https:// doi.org/10.1016/S0883-9026(97)00032-3

Lawless, J. L., \& Fox, R. L. (2012). Men Rule: The Continued Under-Representation of Women in U.S. Politics. Women \& Politics Institute. https://www.american.edu/spa/wpi/upload/2012-Men-RuleReport-web.pdf

Leitch, G. M., \& Volery, T. (2017). Entrepreneurial leadership: Insights and directions. International Small Business fournal: Researching Entrepreneurship, 35(2), 147-156. https://doi. org/10.1177/0266242616681397

Leonidou, L. C. (2004). An Analysis of the Barriers Hindering Small Business Export Development. Journal of Small Business Management, 42(3), 279-302. https://doi.org/10.1111/j.1540627X.2004.00112.x

Mair, J., Marti, I., \& Ventresca, M. J. (2012). Building inclusive markets in rural Bangladesh: How intermediaries work institutional voids. Academy of Management fournal, 55(4), 819-850.

Malmstrom, M., Johansson, J., \& Wincent, J. (2017). Gender Stereotypes and Venture Support Decisions: How Governmental Venture Capitalists Socially Construct Entrepreneurs' Potential. Entrepreneurship: Theory and Practice, 41(5), 833-860. https://doi.org/10.1111/etap.12275

Manzoor, S. (2015). The impact of indigenous culture on female leadership in Pakistan. International Journal of Organizational Leadership, 4(4), 414-429.

Marlow, S., \& Patton, D. (2005). All credit to men? entrepreneurship, finance, and gender. Entrepreneurship: Theory and Practice, 29(6), 717-735. https://doi.org/10.1111/j.1540-6520.2005.00105.x 
Martinez-Jimenez, R. (2009). Research on Women in Family Firms: Current Status and Future Directions. Family Business Review, 22(1), 53-64. https://doi.org/10.1177/0894486508328813

Matsa, D. A., \& Miller, A. R. (2014). Workforce reductions at women-owned businesses in the United States. ILR Review, 67(2), 422-452. https://doi.org/10.1177/001979391406700206

Mayoux, L. (1999). Questioning virtuous spirals: Micro-finance and women's empowerment in Africa. Fournal of International Development, 11(7), 957-984. https://onlinelibrary.wiley.com/doi/ abs / 10.1002/\%28SICI\%291099-1328\%28199911/12\%2911\%3A7\%3C957\%3A\%3AAIDJID623\%3E3.0.CO\%3B2-\%23

Miller, D., \& Le Breton-Miller, I. (2017). Underdog Entrepreneurs: A Model of Challenge-Based Entrepreneurship. Entrepreneurship: Theory and Practice, 41(1), 7-17. https://doi.org/10.1111/ etap. 12253

Muazzam, A., Qayyum, F., \& Cheng, J. (2016). Experiences of Sexual Harassment: Interplay of Working Environment, Depression and Self-Esteem in Pakistani Women. Pakistan fournal of Social and Clinical Psychology, 14(1), 42-46.

Muhammad, N., Warren, L., \& Binte-Saleem, S. (2017). Anything Can Happen, Anytime: The Impact of Conflict on Women's Entrepreneurship in Pakistan. Fournal of Developmental Entrepreneurship, 22(4), 1750025. https://doi.org/10.1142/S108494671750025X

Mumford, T. V., Campion, M. A., \& Morgeson, F. P. (2007). The leadership skills strataplex: Leadership skill requirements across organizational levels. The Leadership Quarterly, 18(2), 154-166.

Nasution, H. N., Mavondo, F. T., Matanda, M. J., \& Ndubisi, N. O. (2011). Entrepreneurship: Its relationship with market orientation and learning orientation and as antecedents to innovation and customer value. Industrial Marketing Management, 40(3), 336-345. https://doi.org/10.1016/j. indmarman.2010.08.002 
Orhan, M., \& Scott, D. (2001). Why women enter into entrepreneurship: An explanatory model. Women in Management Reviewe, 16(5), 232-247. https://doi.org/10.1 108/09649420110395719

Orser, B. J., Riding, A. L., \& Manley, K. (2006). Women entrepreneurs and financial capital. Entrepreneurship: Theory and Practice, 30(5), 643-665. https://doi.org/10.1111/j.15406520.2006.00140.x

Pant, S. K. (2015). Role of the family in entrepreneurship develoment in Nepali society. The fournal of Nepalese Business Studies, 9(1), 37-47.

Patrick, G., Stephens, H., \& Weinstein, A. (2016). Where are all the self-employed women? Push and pull factors influencing female labor market decisions. Small Business Economics, 46(3), 365390. https://doi.org/10.1007/s11187-015-9697-2

Pervez, S. (2013). The Influence of Managerial Mistakes on Entrepreneurial Failures in Pakistan. SSRN, 2178098. https://doi.org/10.2139/ssrn.2178098

Qazi, W., Qureshi, J. A., Raza, S. A., Khan, K. A., \& Qureshi, M. A. (2020). Impact of personality traits and university green entrepreneurial support on students' green entrepreneurial intentions: the moderating role of environmental values. Fournal of Applied Research in Higher Education. emerald. com/insight/content/doi/10.1108/JARHE-05-2020-0130/full/html

Qureshi, J. A. (2012a). The Role of Small \& Medium-size Enterprises in Socio-economic Sustainability in Pakistan. Global Fournal of Management $\mathcal{E}^{2}$ Research, 4(5), 725-741.

Qureshi, J. A. (2012b). Financial Quota of Loans for the SME Sector in Pakistan: A Survey in Karachi. Interdisciplinary Contemporary Research in Business, 10(1), 83-96. 
Qureshi, J. A., Qureshi, M. S., \& Qureshi, M. A. (2018). Mitigating Risk of Failure by Expanding Family Entrepreneurship and Learning from International Franchising Experience of Johnny Rockets: A Case Study in Pakistan. International Journal of Experiential Learning and Case Studies, 3(1), 110-127.

Ramadani, V., Rexhepi, G., Abazi-Alili, H., Beqiri, B., \& Thaçi, A. (2015). A look at female entrepreneurship in Kosovo: An exploratory study. Fournal of Enterprising Communities, 9(3), 277294. https://doi.org/10.1108/JEG-04-2015-0027

Ratten, V. (2016). Female entrepreneurship and the role of customer knowledge development, innovation outcome expectations and culture on intentions to start informal business ventures. International fournal of Entrepreneurship and Small Business, 27(2-3), 262-272. https:/ / doi.org/10.1504/ IJESB.2016.073977

Raymond, L. (2018). Small Business Marketing. In P.-A. Julien (Ed.), The state of the art in small business and entrepreneurship (pp. 180-204). Routledge.

Realini, C., \& Mehta, K. (2015). Financial Inclusion at the Bottom of the Pyramid. FriesenPress.

Ribes-Giner, G., Moya-Glemente, I., Gervelló-Royo, R., \& Perello-Marin, M. R. (2018). Domestic economic and social conditions empowering female entrepreneurship. Journal of Business Research, 89, 182-189. https://doi.org/10.1016/j.jbusres.2017.12.005

Robbins, S. P., \& Judge, T. (2017). Essentials of organizational behavior (14th ed.). Pearson.

Roomi, M. A., \& Parrott, G. (2008). Barriers to Development and Progression of Women Entrepreneurs in Pakistan. The Journal of Entrepreneurship, 17(1), 59-72. https://doi. org/10.1177/097135570701700105 
Salamzadeh, A., \& Kawamorita-Kesim, H. (2015). Startup Companies: Life Cycle and Challenges. In 4th International conference on employment, education and entrepreneurship (EEE), Belgrade, Serbia. https://doi.org/10.2139/ssrn.2628861

Samo, A. H., Qureshi, J. A., \& Buriro, W. M. (2019). Unraveling the Untapped Reservoir: A Phenomenological Inquiry of Women Entrepreneurial Leaders in Pakistan. In Proceedings of Social Enterprise Development Centre (SEDC), LUMS International Conference.

Santos, S. G., \& Neumeyer, X. (2021). Gulture and gender in entrepreneurial teams: the effect on team processes and outcomes. Small Business Economics, 1-16.

Schweizer, K. (2015). Some guidelines concerning the modeling of traits and abilities in test construction. European Fournal of Psychological Assessment, 26(1), 1-2.

Sczesny, S., Bosak, J., Neff, D., \& Schyns, B. (2004). Gender stereotypes and the attribution of leadership traits: A cross-cultural comparison. Sex roles, 51(11-12), 631-645.

Segal, G., Borgia, D., \& Schoenfeld, J. (2005). The motivation to become an entrepreneur. International Fournal of Entrepreneurial Behaviour and Research, 11(1), 42-57. https://doi. $\mathrm{org} / 10.1108 / 13552550510580834$

The World Economic Forum. (2021). Global Gender Gap Report 2021.

Thurik, A. R., Carree, M. A., van Stel, A., \& Audretsch, D. B. (2008). Does self-employment reduce unemployment? Journal of Business Venturing, 23(6), 673-686. https://doi.org/10.1016/j. jbusvent.2008.01.007

Trott, P. (2001). The role of market research in the development of discontinuous new products. European Fournal of Innovation Management, 4(3), 117-126. https://doi.org/10.1108/14601060110390585 
Tushabomwe-Kazooba, C. (2006). Causes of small business failure in Uganda: A case study from Bushenyi and Mbarara towns. African Studies Quarterly, 8(4).

United Nations. (2021). Gender Equality and Women's Empowerment. un.org/sustainabledevelopment/ gender-equality/

Van Gelderen, M., \& Jansen, P. (2006). Autonomy as a start-up motive. Fournal of Small Business and Enterprise Development, 13(1), 23-32. https://doi.org/10.1108/14626000610645289

Wilder, R. A. (2018). Sexual Harassment, Public Transportation, and Labor Market Outcomes for Women: Case Study of Lahore, Pakistan. University of Central Florida.

Wilson, F., \& Tagg, S. (2010). Social constructionism and personal constructivism: Getting the business owner's view on the role of sex and gender. International fournal of Gender and Entrepreneurship, 2(1), 68-82. https://doi.org/10.1108/17566261011026556

Zhang, Y., Duysters, G., \& Cloodt, M. (2014). The role of entrepreneurship education as a predictor of university students' entrepreneurial intention. International Entrepreneurship and Management fournal, 10(3), 623-641. https://doi.org/10.1007/s11365-012-0246-z

Zia, A., Batool, S., \& Yasin, Z. (2016). Women Harassment at Workplace: A Study of Pakistani Television Channels. Global Media Fournal: Pakistan Edition, 9(1), 5. https://aiou.edu.pk/SAB/gmj/ GMJ\%20Spring\%202016/Article_5.pdf 